\title{
OTWARCIE KONFERENCJI
}

Początki muzeów wiąże się $\mathrm{z}$ kolekcjami publicznymi powstałymi w kręgu kultury greckiej. Między innymi wskazuje się na Muzeum Aleksandryjskie założone na początku III w. przed narodzeniem Chrystusa. Jednak $\mathrm{w}$ rzeczywistości był to instytut badawczy. Zasadniczo $\mathrm{w}$ poszukiwaniu początków muzeów należałoby sięgnąć do średniowiecza i powstałych w owym okresie zbiorów w slzarbcach kościelnych oraz należących do panujących. Ciekawsze już kolekcje powstały właściwie na początku czasów nowożytnych. Jeđnalk sama idea muzeów publicznych zrodziła się w okresie oświecenia. Natomiast w Polsce dopiero początek XIX w. przyniósł powstanie pierwszych rnuzeów publicznych. We wszystkich tych inicjatywach, począwszy od okresu średniowiecznego, miał swój udzial Kościół. Zapewne zawsze tym poczynaniom towarzyszyła myśl zabezpieczenia często bezcennych skarbów, które równocześnie były zmaterializowanym wyrazem wysiłków twórczych odchodzących pokolen. W wypadku zbiorów kościelnych przechowywane eksponaty były równocześnie wyrazem ducha i religijności jednostek, a nawet całych społeczności. Instytucje kościelne wyrażały swoją troske przez dobrą organizację różnego rodzaju skarbców i innych odpowiednich pomieszczen. Wreszcie doszło do zorganizowania sieci kościelnych muzeów. Te poczynania zostały zdopingowane przez uświadomienie sobie dokonywanych strat, szczególnis na skutek wojen i nieubłaganego postępu zniszczeń powodowanych przez, ,zab czasu".

Być może te ostatnie powody bardziej odczuwamy na terenie Polski. Nie tylko wojny, ale świadoma i celowa akcja niszczenia dóbr kultury uwrażliwiła nas na konieczność otoczenia dobrą opieką cennych zabytków przeszłości. Tym wszystkim stratom zapobiec może jedynie planowa i zorganizowana opieka. Należy pamiętać o potrójnych zadaniach nowoczesnego muzeum, kktórymi są:

1) gromadzenie i konserwowanie dóbr kultury;

2) naukowe ich opracowanie;

3) wreszcie muzea mają służyć upowszechnianiu sztuki i samych wiadomości o przeszłości. To ostatnie czynią przez udostępnianie swoich zbiorów, organizowanie odczytów itp.

Te wszystkie problemy, troski o właściwą organizację muzeów, a zarazem obawy związane $\mathrm{z}$ niepowetowanymi stratami $\mathrm{w}$ dobrach kultury coraz bardziej nurtowały poszczególne ośrodki kościelne. Między innymi zwrócono na to uwage w Katolickim Uniwersytecie Lubelskim po II wojnie światowej. Uświadamiano sobie konieczność położenia głównego nacisku $\mathrm{w}$ pracy Kościoła na duszpasterstwo. Jednak $\mathrm{z}$ drugiej strony nie można zaprzepaszczać dorobku przeszłości w zakresie dóbr materialnych. Ponadto wszelkie poczynania utrudniać może w znacznym stopniu brak finansów i odpowiedniej kadry fachowej. Dlatego też w latach pięćdzie- 
siątych w KUL zaczęto organizować odpowiednie kursy. Wreszcie w sierpniu r. 1956, w imieniu KUL, ówczesny dyrektor Biblioteki Uniwersyteckiej o. dr Romuald Gustaw zreferował tę sprawę na posiedzeniu Epislzopatu Polski. W dniu 20 grudnia 1956 r. Senat Akademicki KUL podjął uchwałę o powołaniu do życia Ośrodka Archiwów, Bibliotek i Muzeów Kościelnych. Wielki był. w tym wkład ówczesnego rektora, ks. prof. dra Mariana Rechowicza i szeregu innych osób, a między innymi obec-m nych tu ks. prof. dra Stanisława Librowskiego i ks. prof. dr. Władysława Smolenia. Poczynania te poparł prymas Stefan kardynał Wyszyński. Właśnie z jego inicjatywy w czerwcu 1957 r. odbył się I Zjazd Archiwistów, Bibliotekarzy i Muzeologów Kościelnych na Jasnej Górze. Uchwalono wtedy rezolucję wyznaczająca kierunki rozwoju między innymi w dziedzinie muzeów. Głównym zadaniem Ośrodka Archiwów, Bibliotek i Muzeów Kościelnych jest szerzenie i pogłębianie fachowej wiedzy równiéz na odcinku muzealnictwa. Zgodnie z naszym statutem (§ 7) pragniemy umożliwiać wzajemną wymianę doświadczeń oraz dokonywać podsunrowywania wyników pracy. Temu celowi służy właśnie organizowanie spotkań, konferepcji i kursów dla osób zajmujących się ex professo muzealnictwem.

Samo życie dostarcza nam coraz to nowych problemów powiązanych z zabezpieczeniem, konserwacją i udostępnieniem zabytków przeszłości. Dlatego też na naszym spotkaniu wrześniowym 1986 roku postawiliśmy do rozważenia temat: „Alstualne problemy muzealnictwa kościelnego w Polsce". Zapewne wzajemna wymiana doświadczeń dopomoże nam w pracy, a uświadomienie sobie najważniejszych problemów zainicjuje tematykę następnych spotkań. 